\title{
Women on Board: A Research on Problems Faced by Women in the Maritime Sector
}

\author{
Yasemin Nemlioglu Koca (Corresponding author) \\ Maritime Faculty, Kocaeli University, Karamursel, Turkey \\ E-mail: y.nemlioglukoca@kocaeli.edu.tr. \\ ORCID ID: 0000-0003-2533-8078 \\ Murat Kinalibalaban \\ Maritime Faculty, Kocaeli University, Karamursel, Turkey \\ E-mail: muratkinalibalaban@gmail.com \\ ORCID ID: 0000-0002-4948-8866
}

\begin{abstract}
Nowadays, women have started to work in the business areas that were previously open to male employment, and maritime sector is one of these business areas. The most prominent attribute of the maritime sector is that it is maintained in an international environment, under natural conditions and specific rules. These challenging conditions and their impacts in maritime business are felt more physically and mentally on women compared to other sectors. In addition, the fact that professional conditions, work environment and expected outputs are arranged especially for men causes women to face many problems in the maritime sector. Except physical conditions, defining the profession as masculine causes negative effects and pressures on female employees. Under the influence of general attitude, prejudice against women, gender discrimination, mobbing, glass ceiling syndrome and inequality in salary may be faced. The validity of this situation in the maritime sector in Turkey as in many countries has also proved as a result of various researches. In this study attempted to determine, the priorities of the problems faced by women in the maritime sector in Turkey. As a result of the survey conducted to determine the problems faced by women in business life in maritime sector, the most common sexist problems faced by female employees were mobbing, different credentials of male and female employees, and male employees rising faster in careers than women.
\end{abstract}

Keywords: Maritime, Women, Gender Discrimination, Mobbing

DOI: $10.7176 / \mathrm{JSTR} / 6-09-12$

\section{Denizde Kadın: Kadınların Denizcilik Sektöründe Karşılaştıkları Sorunlara İlişskin Bir Araştırma}

Öz

Günümüzde kadınlar, daha önce erkek istihdamına açık olan iş alanlarında da çalışmaya başlamıştır ve denizcilik sektörü de bu alanlardan biridir. Denizcilik sektörünün en belirgin özelliği uluslararası bir ortamda, doğal şartlar ve kendine özgü kurallar altında sürdürülür olmasıdır. Denizcilik çalışma hayatındaki bu zorlayıcı şartlar ve etkileri, diğer sektörlere göre kadınların üzerinde fiziksel ve ruhsal olarak daha fazla hissedilir. Ayrıca mesleki şartların, iş ortamının ve işten beklenen çıktıların özellikle erkeklere göre düzenlenmiş olması, kadınların denizcilik sektöründe birçok sorunla karşılaşmasına neden olmaktadır. Fiziksel şartların dışında mesleğin eril olarak tanımlanması kadın çalışanlar üzerinde olumsuz etki ve baskılara yol açmakta, genel tutumun etkisi altında kadına karşı önyargı, cinsiyet ayrımcılığ 1 , mobbing (bezdirme), cam tavan sendromu (belirti/bulgu) ve ücret eşitsizliği gibi olgularla karşı karşıya kalınabilmektedir. Denizcilik sektöründe bu durumun geçerliliği birçok ülkede olduğu

113 | P a g e

www.iiste.org 
gibi Türkiye'de de çeşitli araştırmalar sonucunda ortaya konulmuştur. Bu çalş̧mada öncelikle Türkiye'de denizcilik sektöründeki kadınların karşılaştığı sorunların belirlenmesi amaçlanmıştır. Sektörde kadının iş hayatında karşılaştığı sorunların belirlenmesine yönelik yapılan anket çalışması sonucunda denizcilik sektöründe kadın çalışanların en sık karşılaştığ 1 cinsiyetçi sorunlar mobbing uygulamaları, kadın ve erkek çalışanların sözlerine farklı güven gösterilmesi, erkek çalışanların kariyerlerinde kadınlara göre daha hızlı yükselmesi olarak belirlenmiştir.

\section{Anahtar Kelimeler: Denizcilik, Kadın, Cinsiyet Ayrımcılı̆̆ı, Mobbing}

\section{Giriş}

Kadının ekonomik anlamda iş hayatına atılması Sanayi Devrimiyle başlamıştır. Ataerkil toplum yapısı içinde sosyal hayatta ikinci planda olan kadının iş alanındaki konumunda da değişiklik olmamış, çalışma hayatında kadına "yedek işgücü” olarak bakılmıştır. İlk zamanlarda kadının ücretli olarak iş hayatına katılma oranı oldukça azken, II. Dünya Savaşı sonrasında artan işgücü ihtiyacı ve erkek nüfusun azalması sonucunda kadın işgücüne yönelik talepte yüksek artış meydana gelmiştir. 1950'li yıllardan günümüze, kadınların işgücüne katılımları yalnızca sanayileşmiş ülkelerde değil, tüm ülkelerde artış göstermiş; öğrenimde firsat eşitliği arttıkça, kadınların tüm çalışma alanlarında daha fazla sayıda istihdam edildikleri, gittikçe daha fazla sayıda kadının erkeklerin hâkimiyet alanında olduğu düşünülen meslekleri icra ettiği, bir kısmının üst düzey yönetimde yer almaya ve birçoğunun da kendi işlerini kurmaya başladıkları görülmüştür. Bununla birlikte kadınların çalışma hayatında ve ekonomik faaliyetlerde erkeklerle aynı ve/veya yakın oranlarda temsil edilmedikleri izlenmektedir. Ülke yönetimlerinde ve özellikle şirketlerin üst düzey iş pozisyonlarında, kadınların oranının erkeklerle kıyaslandığında son derece sınırlı sayıda olduğu, kadının iş hayatındaki yerinin ve ağırlığının artmasına rağmen liderler/önderler, üst düzey yöneticiler içinde kadınların sayısının az olduğu gözlemlenmektedir.

Kadın işgücü arzı ve talebinde karışık ve çok yönlü etkenler bulunmakla birlikte, genel olarak kadınların çalışma hayatına girişte sosyo-kültürel etkenler büyük rol oynamaktadır. Kadın işgücü arzını etkileyen unsurların başında toplumsal cinsiyete dayalı işbölümü ve bu işbölümü sonucu belirlenen toplumsal cinsiyet rolleri yer alırken, özellikle kadınları ev işleri, çocuk, hasta ve yaşlı bakımından yükümlü/sorumlu olmakla sınırlandıran bakış açısı, kadının iş aramasını, çalışma hayatına girmesini ve sürdürmesini büyük oranda engellemektedir. İşgücü piyasasında cinsiyet esaslı mesleki ayrışmaya ve uzmanlaşmaya bağ lı olarak kadınlara önerilen işlerin sınırlılığı, çalışma şartlarının ağırlığ azlı̆̆ı, çalışmayı kadınlar açısından cazip olmaktan çkkarmaktadır. Bu nedenle çifte sorumluluk üstlenmek istemeyen kadınlar, çalı̧smanın getirisinin düşük olduğu durumlarda ev içindeki yükümlülükleri ile yetinmeyi tercih etmektedir (Toksöz, 2007: 58). Kadınların çalışma hayatına katılmalarını engelleyen etkenler arasında; yeterli eğitim alamamaları ve/veya eğitim düzeylerinin düşük olması, bilgi ve beceri eksikliği nedeniyle kalifiye işler için uygun görülmemeleri, uzmanlaşmanın geri planda kalması, informal (resmi olmayan, kayıtsız) işlerde düşük ücret karşıllı̆ında ve sosyal güvenceleri olmadan çalı̧̧mak zorunda kalmaları, aldıkları ücretin düşük ve çalıştıkları işlerin geçici olması, çocuk ve yaşı bakım hizmetlerinin yetersizliği nedeniyle ev ve iş hayatını birlikte yürütmek zorunda kalmaları, köyden şehre göç sonucunda şehirleşmenin aileye getirdiği sorunlar gösterilebilir.

$\mathrm{Bu}$ makale kadın cinsiyetine ilişkin önyargı ve ayrımcılık algısının doğal sonucu olan toplumsal düşünce geleneği ve iş-çalışma ilişkileri içerisinde ortaya çıkan sorunların belirlenmesi, bütüncül bir bakışla anılan sorunların bir çözümlemeyle ortaya konmasını amaçlamaktadır. Çalışma geniş bir tipoloji ve örneklem özelliği sergileyen denizcilik sektörü çalışanlarıyla sınırlandırılmış olmakla birlikte, anılan sorunlara yönelik çoğulcu yaklaşıma güçlü bir örnek oluşturarak genellemelere ulaşmaya ve bu genellemeleri eleştirel açıdan irdelemeye olanak sağlayacak niteliktedir.

\subsection{Kadının İş Hayatında Karşılaştığ Sorunlar}

Kadınların iş hayatındaki karşılaştı̆̆ sorunlar çoğunlukla sosyal ve ekonomik alanda olmakla birlikte, cinsiyete dayalı düşünce ve eylemler kapsamında cinsiyet önyargısı, cinsiyet ayrımcılığı, mobbing, cam tavan sendromu ve ücret eşitsizliği olarak yer almaktadır. Cinsiyet ayrımcılığı günümüz kurum, işletme ve örgütlerde önemli bir sorun olmaya devam etmektedir. Toplumlar erkek-kadın davranışlarını, sahip olunması gereken kişisel ve bireysel özellikleri, cinsiyete bağlı olarak üstlenilen rolleri belirleyen, formal ve informal kurallar yaratmaktadırlar. Bu kurallar kadınların, insanların zihninde önceden belirlenen sınırlar ve normlar içinde algılanmasına, davranışlarının önyargılar çerçevesinde 
değerlendirilmesine neden olur ki, bunun sonucunda kadınlar iş hayatında cinsiyetlerinden dolayı önyargı ve ayrımcılıkla karşı karşıya kalmaktadır. Cinsel ayrımcılık (sex discrimination) ya da cinsiyetçilik (sexism) yanlış ve katı bir genellemeyle, kadınlara karşı düşmanca önyargılar doğrultusunda yapılan ayrımcılıktır ve erkeklerin kendi cinsiyetlerinden dolayı kadınları maruz bıraktığı ayrımcı davranışlar olarak görülmektedir. (Glick ve Fiske, 1996:491). Cinsel ayrımcılık olumsuz davranışlardan daha çok; saygınlık, güç ve hak dağılımının bireysel özelliklere göre değil cinsiyete göre yapılmasıdır (Parrillo, 2005:192; Aktaran: Mahmutoğlu, 2017:5). Cinsiyetçi davranışlar düşmanca (hostile) ve korumacı (benevolent) olarak temelde iki şekilde görülmektedir. Düşmanca cinsiyetçilik, geleneksel tanımda yer aldığı gibi temelinde nefret duyguları barındıran, kadını aşağı gören, düşmanca davranışlar ve tututmlar içeren cinsiyetçiliktir. Korumacı cinsiyetçilik ise, kadını fiziksel ve duygusal olarak güçsüz görerek ona korumacı şekilde yaklaşan ve kadınlar tarafindan da kısmen olumlu algılanan davranış şeklidir (Dardenne ve diğerleri, 2007:775). Bununla birlikte, cinsiyet ayrımcılığı uygulayanın yani genelde erkeklerin duyguları, sosyal davranışları, öznel olarak olumlu doğası ve yakınlık girişimleri standart önyargı kavramlarına uymaz. Kimi zaman erkekler kadınları birçok olumlu özellikle tanımlamakla birlikte, bu olumlu özellikler işlevsel ve sistematik boyutlarla yani analitik düşünme, koordinasyon, yenilikçilik vb. değil, sosyal-duygusal alanlarla ile ilgilidir. Bu nedenle cinsiyet ayrımcılığı ile cinsiyetçilik iç içe geçmiş davranışlar ve uygulamalar olarak görülmektedir. Cinsiyet ayrımcılığı, kişinin yetkinlikleri ve/veya başarısından daha çok cinsiyetine bağlı olarak, kadın veya erkek kimliğinden dolayı iş hayatında farklı ve/veya benzer davranışlar göstermesidir. $\mathrm{Bu}$ durumun varlığının en önemli göstergesi ise çalışan kadınların iş hayatında kendilerine yönelik cinsiyet ayrımcılığı içeren davranışlar ve tutumlar algıladıklarını belirtmeleridir. Kadınlar için cinsiyet ayrımcılığının algılanması, belirli çıktılarla ilgilidir ve bunlar arasında iş hayatındaki saygınlık seviyesi, düşük güç algısı, yüksek iş çatışmaları, düşük özgüven, bunalım ve endişe durumu sayılabilir (Foster, 2000:96). Algılanan cinsiyet ayrımcılığı, kişinin kendi iş hayatındaki deneyimleriyle ilişkiliyken, kadınlara karşı algılanan cinsiyet önyargısı tamamen kadınların ve erkeklerin kişisel kararlarında ve çalışma şartlarında karşılaştıkları durumlar nedeniyle ortaya çıkmaktadır (Elkins ve diğerleri, 2001: 4). Kadınların bu ayrımcılığı kendilerinden daha çok, bulundukları gruba, yani doğrudan kadın cinsiyetine yönelik algılamaları erkek ve kadınlar arasındaki temel ayrılık olarak gözlemlenmektedir. Sosyal Kimlik Teorisi’ne göre gruplar, üyeleri arasında sosyal statü ayrımı yaptığında daha güçlü olacaktır ki, bu durum üyelik farklılıklarını haklı çıkaran sosyal ideolojiler oluşturmaya yardımcı olur (Yuki, 2003: 167). Erkek egemen sistemde rekabetçi bir cinsiyet farklılaşması yapının sürekliliği için sosyal bir gerekçe oluşturur ve önemli sosyal kurumları yönetmek için yalnızca erkeklerin gerekli özelliklere sahip olduğunu kabul eder. Dolayısıyla kadınların cinsiyet ayrımcılığını bulunduğu grubun cinsiyetine yönelik algılaması ve davranışları üzerinde etkisini olduğunu düşünmesi de bu duruma uygun bir sonuç olarak kabul edilebilir. Ayrıca cinsiyet ayrımcılığında kadın çalışanlar işyerlerinde cinsiyet ayrımcılığından şikayet eden diğer kadınları yani hemcinslerini erkeklere göre daha fazla destekledikleri görülmektedir. Kadınların bu durumu erkeklerin aksine, cinsiyet ayrımcılığına maruz kalan bireyin kişisel özelliklerinden çok bağlı olduğu gruba dayandırdığı anlaşılmaktadır. Bu sonuç, grup içinde düşük düzeyli grup üyelerinin yüksek düzeyli grup üyelerinden daha fazla desteklemeye yatkın olduğunu kabul eden yaklaşımlara uymaktadır.

Mobbing kavramı işyerinde psiko-şiddet, psiko-terör ve zorbalık, duygusal ve ruhsal taciz, yıldırmaya yönelik psikolojik saldırı gibi kavramları içerecek şekilde, en önemli özelliği iş yerinde gerçekleşiyor olmasıyla tanımlanan eylemlerdir. Mobbing haksız suçlamalar, küçük düşürmeler, tacizler, duygusal baskılar ve psiko-terör uygulamak yoluyla bir kişiyi iş yerinden dışlamayı amaçlayan kötü niyetli bir eylemdir (Davenport ve diğerleri, 2003:22). Belli bir süreçte düşmanca, psikolojik ve ruhsal, ancak fiziksel olmayan davranışların düzenli şekilde uygulanması olarak görülen mobbing eylemlerinde, eyleme mazur kalan kişi ile uygulayan kişi arasında güç eşitsizliği bulunmaktadır. Kurum içerisinde kim tarafından uygulandığına göre değişmek üzere üstler tarafından uygulanan yukarıdan aşağıya doğru mobbing (dikey), astlar tarafindan uygulanan aşağıdan yukarıya doğru mobbing ve iş arkadaşları tarafından uygulanan eşdeğerler arasında mobbing (yatay) olarak sınıflandırılmaktadır. Eylemin temelinde sosyal imajın tehdit edilmesi, yaş farkı, politik ve sosyo-kültürel farklılık, kayırma, hiyerarşik yapının çiğnenmesi, bireyler arasında kıskançlık, çekememe, yarışma vb. nedenler yer alırken (Adalar Solmaz, 2015: 21); anlaşmazlık, çatışma, saldırganlık, yönetiminin devreye girmesi, yanlış yakıştırmalar, tanımlarla damgalama, işe son verme ve hatta duygusal, psikolojik ve cinsel taciz gibi süreçler içinde gerçekleşmektedir. Tüm bu süreçler kadınlar tarafından dile getirildiğinde ise, "kadınlar cinsiyetçiliğin varlığını abartıyor, erkek-kadın ilişkileri bir güç mücadelesi olarak karakterize ediliyor, kadınlar erkeklerden faydalanıyor, kadınlar erkekleri manipüle etmek ve kontrol etmek için

115 | P a g e

www.iiste.org 
cinsel kimliğini kullanıyor vb." ifadelerle karşıtlık oluşturulmaktadır. Bu temalar, kadını açıç̧a aşağılayan ifadeleri içermeyen, ancak doğrudan feminizmle ilişkilendirilen karşı bir tepki olarak geliştirilirken, erkek ve kadın arasındaki güç ilişkileriyle ilgili kaygı içeren modern görüşü de yansitmaktadır.

Cam tavan, kadınlar ile üst yönetim arasında yer alan ve onların uzmanlık, başarı, liyakatlerine bakılmaksızın ilerlemelerini engelleyen, açıkça görülmeyen, aynı zamanda aşılamayan engelleri nitelendirmektedir. Cam tavan engelleri, kurum/işletmelerde rekabet üstünlüğü yaratabilecek çeșitli niteliklere sahip kişilerin üst düzey yönetim kademelerinde görev alamamasına ve işletmelerin verimliliğine katkıda bulunabilecek yeteneklerin kullanılmamasına neden olmaktadır (Aytaç,1997:2728; Aktaran: Mızrahı ve Aracı,2010:217). İşletme/kurumlarda ve örgütlerde cam tavan oluşumuna neden olan etkenler bireysel, örgütsel ve toplumsal olarak gruplandırılabilir:

- Bireysel etkenlerden kaynaklanan engeller: çoklu rol üstlenme ve kadınların kişisel tercihleri,

- Örgütsel etkenlerden kaynaklanan engeller: örgüt kültürü ve politikaları, mentor (yönder) eksikliği, tokenizm (yapmacıklık), informal iletişim ağlarına katılamama,

- Toplumsal etkenlerden kaynaklanan engeller: mesleki ayrım, stereotipler (Cinsiyetle bağdaştırılan kalıplaşmış önyargılar) (KSSGM, 1998).

Kadının birey, çalı̧an, eş, anne olarak birçok role sahip olması özel, iş ve aile hayat alanını ve bu alanlardaki ilişkilerini dengeleyememesi, kadının üst düzey iş pozisyonlarına gelmesinde engelleyici bir durumdur. Zamanını ve enerjisini bu alanlar arasında dengesizce harcayan kadın bölünmüşlük yaşamakta, kendini işine verememekte, üst düzey iş pozisyonlarından kaçınmakta, kendini geliştirme ve şartlarını değiş̧irmekte zorlanmakta, erkek çalışanlarla aynı şartlar içinde olmasına rağmen kendisini kabul ettirmek ve başarı sağlamak için daha fazla emek sarf etmekte, onaylanmak zorunda kalmakta ve son aşamada kariyerine son vermektedir. Ayrıca işletme/kurumların rol tanımları ve bu rollerden beklentileri nedeniyle üst düzey iş pozisyonları sınırlamaları, kadın çalışanların örgütlerde daha az gelişme firsatıyla karşılaşmaları, erkek çalışanlar ve üstleri/yöneticileri tarafından dışlanmaları, erkeklerin egemen olduğu örgütlerde azınlık olduklarının hissettirilmesi, belirsiz konumda bırakılmaları, ilişki ağlarına katılım konusunda etkin olamamaları üst düzey iș pozisyonlarında görev alma olasılıklarını azaltmaktadır. Çalışma alanında çoğunluk cinsiyetin azınlık cinsiyeti etki oltında tutması olarak tanımlanan tokenizm ise, eril bir örgüt yapısında çalışan kadınların kararlılık, sertlik, hırslılık, iddialılık, otoriterlik ve hatta totaliterlik gibi erkeksi davranışları gösterme eğilimi ve/veya zorunluluğu olarak ortaya çıkmaktadır (Katkat, 2000:57-59). Nesilden nesilen aktarılan, değerler ve kurallar gibi sosyalleşme yoluyla üretilen toplumsal cinsiyet ise büyük ölçüde tokenizmin temelini oluşturmaktadır. Kavramsal olarak, toplumsal cinsiyetin temelinde ise cinsiyetçi inançlar, tutumlar, erkek güdüleri (egemenlik, otorite, korumacılık vb.) bulunsa da, sosyal öğrenme, kültürel aktarım ve hatta kadınlar tarafından da bu kavramın benimsenmesi de bireylerin davranışlarında öne çıkmaktadır. Dolayısıyla kadın ve erkeklerin anatomik, fiziksel ve ruhsal olarak farklı özelliklere sahip olması farklı alanlarda ve disiplinlerde uzmanlaşıp, beceri ve yetenek kazanmasına ve dolayısıyla farklı işlerde istihdam edilmelerine yol açmaktadır. Cinsiyete ilişkin rol stereotipleri meslek seçiminde doğrudan etkili olmakta ve bireylerin, cinsiyetlerine göre olduğu düşünülen ve kabul edilen meslekleri seçmeleri istenmektedir. Yüksek ücretli ve saygın mesleklere erkekler egemen olmakta, kadınların bu tür işlere talip olması beklentilere aykırı bulunmaktadır. Bu kültürel stereotiplerin ışığında liderlik erkekler, ast pozisyonlar ise kadınlar için uygun görülmektedir (Katkat, 2000:52). Dolayısıyla cinsiyete ve cinsiyet ayrımına dayanan iş bölümü kısıtlayıcı, sınırlayıcı ve engelleyici bir sistem olarak işlev görmekte, kadın çalışanların üst düzey iş pozisyonları için hazırlanmalarını ve sonrasında ulaşmalarını zorlaştırırken, genel olarak da iş hayatında cam tavan engeli yaratmaktadır.

Cinsiyetçi katmanlaşmanın en önemli sonuçlarından birisi de eşdeğerde iş yapan kadın ve erkek çalışan arasındaki ücret farkı ve bu farkın yüksekliğidir. Eşit işe eşit ücret konusunda yasa üzerinde kadınerkek eşitliği sağlanmış olmasına rağmen, uygulamada gerçek bir eşitlikten söz edilememektedir. Kadın ve erkek arasındaki ortalama toplam saat başına kazançlar arasındaki farklılık yine cinsiyete göre ücret eşitsizliğini yaratmaktadır. Düşük istihdam oranı, yarı zamanlı çalışma oranları, kariyer bölünmesi ve sonlandırılması, işgücü piyasasında ayrım, doğrudan ya da dolaylı ayrımcılık, kadınların gelir ve kazançlarında cinsiyetler arası ödeme eşitsizliğini arttırmaktadır. Küresel ölçekte cinsiyete göre ücret eşitsizliği \%23 olarak tahmin edilmektedir. Bir başka ifadeyle, kadınlar erkeklerin kazandığının ancak \%77'sini kazanmaktadır. Son zamanlarda cinsiyete göre ücret eşitsizliğini azaltmada birtakım gelişmeler olmasına rağmen bu yeterli gelmemekte ve mevcut eğilimin devam edeceği göze alındığında cinsiyete göre ücret eşitsizliğini kapatmanın ortalama 70 yıl alacağı Uluslararası Çalışma Örgütü (ILO) tarafindan belirtilmektedir (ILO, 2016:XVI).

116 | P a g e

www.iiste.org 


\subsection{Kadınların Denizcilik Sektöründe Karşılaştığ Sorunlar}

Her geçen gün gelişen ve büyüyen denizcilik sektörü lojistik alanda daha çok paya sahip olmakta ve buna paralel olarak bu iş alanında çalışacak daha fazla insana ihtiyaç duymaktadır. Denizcilik sektörü gemilerdeki iş düzeninin yanı sıra, karada bu gemilere yönelik hizmet işlemlerini içerirken; çalışanlar gemi, yük, çevresel güvenlik ve doğal şartlar gibi çok yönlü bileşenleri yönetmek zorundadırlar. Sonuçta sektörde faaliyet gösteren şirket/kurumların bir işletme olması, gelir ve katma değer üretme zorunluluğunun yanı sıra operasyonların karmaşıklı̆̆ı, karadan uzak hayat, geniş ve uzun çalışma saatleri, aile ve sosyal hayattan yoksunluk vb. mesleki etkenler çalışanları zorlamaktadır. Sektörde verimliliği etkileyen en önemli unsurlardan biri çalışanların performansıdır ki, emek yoğun bir sektör olan denizcilik sektöründe çalışma şartları, iş yükü ve yoğunluğu verimliliği doğrudan etkilemektedir. Denizcilik sektörünün yalnızca lojistikten ibaret olmayışı, aynı zamanda bir hizmet sektörü olması da zaman içinde denizcilikte çalışan kadın sayısını ve önemini/değerini arttırmıştır. Ancak dünya genelinde olduğu gibi cinsiyet ayrımcıllğının bu sektörde de aşılamaması ve cinsiyet ayrımcilığının kaldırılması konusunda yeterli desteğin bulunmaması, kadın çalışanların potansiyelinin tam olarak değerlendirilememesine neden olmaktadır.

Denizcilik sektöründe kadınlar, başta marina ve liman işletmeleri, deniz turizmi işletmeleri, gemi işletmeciliği gibi alanlarda çeşitli görev ve pozisyonlarda çalışmaktadırlar. Gemilerde daha çok yönetim seviyesinde güverte, makine ve elektroteknik zabiti ve yönetim dışında gemi aşçısı, turistik gemilerde ise yat kaptanı olarak görev almaktadırlar. Karada ise tüm denizcilik işletmelerinde her türlü görev ve pozisyonda çalışmaktadırlar. Kadın çalışanların ağırlıklı olarak sektörün karasal alanlarında çalışıyor olması, sektördeki cinsiyet temelli ayrımcılığın bir göstergesi olarak kabul edilebilir. Ayrıca Türkiye'de Ulaştırma, Denizcilik ve Haberleşme Bakanlığı (UDHB-Ulaştıma ve Altyapı Bakanlığı) tarafından gemide çalışanları tanımlayan mevzuatta geçen "Gemiadamı" kavramı doğrudan cinsiyet ayrımcılığını gösteren bir ifade olarak kanun ve yönetmeliklerde yer almaktadır (Yönetmelik, 2018). Ayrıca kadın çalışanların en yoğun olarak sektörün alt çalışma alanı deniz turizmi işletmeleri ve marinalarda olduğu belirlenmesine rağmen, bu işletmelerde dahi kadınların oranı ancak \%10-15'i bulmaktadır (Arlı, 2013:286). Bu durumun temelinde sektörün erkek gücüne dayalı, fiziksel faaliyeti yüksek, çalışma şartları zor ve iş tatmini düşük olduğu düşüncesi yer almaktadır. Kadın çalışanların özellikle, "mesleğin bir erkek mesleği olduğu", "mesleğe uygun olmadıkları" ve "gemiye uğursuzluk getirdikleri" gibi söylemler ve düşünceler doğrultusunda cinsiyet ayrımcılığına, kalıplaşmış önyargılara dayanan tutum ve davranışlarla deniz, gemi ve diğer denizcilik işletmelerinde çalışmaktan uzaklaştırıldıkları görülmektedir. Ayrıca sektördeki erkeklerin kadın çalışanları düşük konumda görmeleri nedeniyle içinde yer aldıkları örgüt ve kurum/işletmenin başarısını olumsuz etkiledikleri, kadınları örgütün gereksinimlerine aykırı olarak algıladıkları anlaşılmaktadır. Dolayısıyla sektörde kadın çalışanlara önyargıyla yaklaşılmakta ve cinsiyet ayrımcılığı yapılmakta; işe alım, ilerleme ve yükselmede bu durum süregelen sorunlar yaratmaktadır (Nemlioğlu Koca, 2015:156). Kadın çalışanlar süreç içinde eşitsizlikten kaynaklanan bir savaşın içinde yer almakta, bu nedenle sistem içinde farklı davranış ve tutumlar sergileyebilmektedir. Sektörde çalışan kadınlar bu savaştan galip çıkmak için eril bir birey gibi davranmaya ve kendini gereğinden fazla erkeksi nitelikler göstermeye çalışmaktadır. Kişiyi rencide eden bir olgu olarak kabul edilebilecek bu durum, cam tavan sendromuna yakalanmasına, iş pozisyonlarında yükselemeyeceği düşüncesiyle var olan konumunu kabullenmesine, potansiyelini tam olarak kullanamamasına ve hatta yavaş yavaş kaybetmesine neden olmaktadır. Ayrıca kadın çalışanlar süreç içinde bireysel olarak uykusuzluk, yorgunluk, madde bağımlılı̆̆ı, ağrı, bitkinlik, öfke/ankisiyet, duyarlılık ya da duyarsızlık, bunalım, iş kaybı, aile içi vb. sorunlar; kurumsal olarak ise verimsizlik, hata riskinde artış, erteleme, devamsızlık, uzaklaşma, çatışma, kaza ve yaralanma riskinde artış, yenilik ve üretkenlikte düşüs, rol çatışması ve rol belirsizliği, dolayısıyla iş hayatında nicelik ve niteliksel bozulma ve kayıplar vb. sorunlar yaşanmaktadır. Bu etkilerin sonucunda ise olumsuz, katı tutum ve davranışlar sergilemekte; yetersiz, verimsiz ve tükenmiş hissetmekte; tepkisiz, duygusuz, özgüvensiz, ilgisiz, huzursuz, sabırsız vb. şekilde davranmaktadır.

Uluslararası alanda cinsiyet eşitliğinin sağlanması Birleşmiş Milletler'in (United Nations-BM) temel hedeflerinden biridir. 2015 y1lında BM üyesi devletler tarafindan kabul edilen ve uygulamaya alınan sürdürülebilir gelişme hedeflerinden biri Cinsiyet Eşitliğinin Sağlanması başlığıdır. Bu kapsamda Uluslararası Denizcilik Örgütü (International Maritime Organization-IMO) tarafindan Toplumsal Cinsiyet Eşitliği ve Kapasite Oluşturma Programı yürütülmeye başlamıştır. Bu programda Woman in Maritime (Denizcilikte Kadın) ve Denizcilik Sektöründe Kadınların Entegrasyonu (Integration of Women in the Maritime Sector-IWMS) başlıklarıyla çalışmalar yürütülmektedir. Bu çalışmalarla denizcilik sektöründe yönetimde, limanlarda ve denizcilik eğitiminde kariyer ve mesleki gelişim

117 | P a g e

www.iiste.org 
fırsatları için kadınların teşvik edilmesi ve Cinsiyet Eşitliğinin Sağlanması hedeflerine ulaşmak amaçlanmaktadır. IMO tarafından 2019 yılı Dünya Denizcilik Günü’nün teması ise "Empowering Women in the Maritime Community (Denizcilikte Kadını Güçlendirmek)” olarak belirlenmiştir (IMO, 2019).

\section{Türkiye’de Denizcilik Sektöründe Kadınların Karşılaştığı Sorunların Belirlenmesine Yönelik Örnek Uygulama}

Dünyada örnekleri olduğu üzere Türkiye'de de denizcilik sektöründe kadınların çeşitli zorluklarla, cinsiyete dayalı ayrımcılık ve önyargıyla karşılaştığı düşünülmektedir. Bu sorunların belirlenmesi amacıyla yapılan araştırmada, Türkiye genelinde faaliyet gösteren denizcilik şirketlerindeki çalışanlar aracılığıyla 2019 yılı içinde bir çalışma yapılmıştır. Çalışmada veri toplama yöntemi olarak çoktan seçmeli sorulardan oluşan anket tekniği kullanılmıştır. Anketin uygulanacağı örneklemin belirlenmesinde tesadüfi olmayan örnekleme yöntemlerinden kolayda örnekleme kullanılmıştır. Örneklemin ana kitleyi temsiliyetinin yüksek olması zorunluluğu göze alınarak, mümkün olduğunca denizcilik sektörünün farklı alt dallarında faaliyet gösteren işletme/kurumlardaki (marina, acente, liman, tersane, brokerlik, armatörlük ve forvarder (taşıma komisyoncusu) işletmeleri vb.) çalışanlara ulaşılmaya çalışılmıştır. Çevrimiçi/online hazırlanan anket soruları katılımcılara e-posta yoluyla ulaştırılmıştır. Anket formları çalışmanın örneklemini oluşturan denizcilik şirketleri çalışanları tarafindan gönüllü olarak 66 adet doldurulmuş ve toplam 66 adet olarak değerlendirmeye alınmıştır. Katılımcıların denizcilik sektöründe kadınların karşılaştığı sorunlara yönelik algılarının ölçülmesi amacıyla, kadınların iş hayatında karşılaştığı bilinen sorun alanlarını içeren 10 (on) sorudan oluşan anket hazırlanmıştır. Anket sorularının belirlenmesinde literatürde yer alan Arlı, 2013; Nemlioğlu Koca, 2015; Zorba, 2016; Kurt, 2010; Kuleyin, Köseoğlu, Töz, 2013; Aydın, 2015; Borovnik, 2011 kaynaklarındaki çalışmalardan, sektörle ilgili yayınlardan ve yapılan ön görüşmelerden yararlanılmıştır. Yanıtlara ilişkin ölçek Beşli Likert olarak düzenlenmiştir (Kesinlikle Katılıyorum=5, Kesinlikle Katılmıyorum=1). Ölçek güvenilirliği Cronbach’s Alfa değeri olarak 0,67-0,86 olarak hesaplanmıştır. Ankette öncelikle işletme/kurumlarda çalışan personelin cinsiyete dayalı sorunlarla karşılaşıp karşılaşmadığı, sonrasında ise katılımcılar üzerinden sektörün kadınların karşılaştığı bu sorunlara yönelik bakış açısı belirlenmeye çalışılmıştır.

Tablo 1. Katılımcıların Yaş, Eğitim, Kurum/İşletme Özellikleri, Kadınlara Yönelik Cinsiyete Dayalı Sorunlara Yönelik Katılım Durumu

\begin{tabular}{|l|c|c|}
\hline Gruplar & Frekans (n) & Yüzde (\%) \\
\hline 1. Lütfen yaşınızı belirtiniz. & 35 & 53 \\
\hline $20-30$ & 19 & 29 \\
\hline $31-40$ & 10 & 15 \\
\hline $41-50$ & 2 & 3 \\
\hline $51-60$ & 0 & 0 \\
\hline $61+$ & \multicolumn{2}{|c|}{} \\
\hline 2. Lütfen eğitim durumunuzu belirtiniz. & 10 & 7 \\
\hline İlk Öğretim-Ortaöğretim & 44 & 15 \\
\hline Önlisans & 7 & 67 \\
\hline Lisans & 14 & 11 \\
\hline Yüksek Lisans-Doktora & 8 & 22 \\
\hline 3. Lütfen şirketiniz/kurumunuzun çalışma alanını belirtiniz. & 13 \\
\hline Forvarder & 9 & 6 \\
\hline Liman & 4 & 14 \\
\hline Brokerlik & 14 & \\
\hline Tersane & \multicolumn{2}{|c|}{} \\
\hline
\end{tabular}

118 | P a g e

www.iiste.org 


\begin{tabular}{|l|c|c|}
\hline Gümrük & 1 & 2 \\
\hline Marina & 4 & 6 \\
\hline Acente & 20 & 21 \\
\hline Armatörlük & 1 & 2 \\
\hline Danışmanlık & 1 & 2 \\
\hline Gemi & 1 & 80 \\
\hline 4. Denizcilik sektöründe kadınların cinsiyete dayalı sorunlarla karşılaştığını düşünüyor musunuz? \\
\hline Evet & 53 & 20 \\
\hline Hayır & 13 & \multicolumn{2}{|c|}{} \\
\hline
\end{tabular}

Anketin analizi sonucunda ilk bölümdeki katılımcıların demografik özelliklerine ilişkin bulgular incelendiğinde \%53'ünün 20-30 yaş aralığında, \%29'unun 31-40 yaş aralığında, \%15'inin 41-50 yaş aralığında, \%3'ünün 51-60 yaş aralığında olduğu görülmektedir. Eğitim durumlarında ise katılımcıların $\% 7$ 'sinin ortaöğretim, \%15'inin önlisans, \%67'sinin lisans, \%11'inin yükseklisans-doktora mezunu olduğu görülmektedir. Katılımcıların denizcilik sektöründeki alt çalışma alanlarına bakıldığında \% 31 'inin acentelerde, \%22'sinin forvarder, \%13'ünün liman, \%14'ünün brokerlik, \%4'sının marina, \%2'şer olmak üzere gümrük, armatörlük, danışmanlık ve gemi işletmelerinde görev aldıkları görülmektedir. Özellikle katılımcıların genç yaşlarda olmaları göze alındığında sektörde iş hayatının zorluklarına uyum, verimin artırılmasında bireysel destekler ve farkındalık etkenleri önemli olmaktadır. Katılımcıların denizcilik sektöründe kadınların cinsiyete dayalı sorunlarla karşılaşmalarına yönelik yanıtlarına bakıldığında \%80 oranında kadınların cinsiyetlerinden kaynaklanan sorunlarla karşılaştığını düşündükleri görülmektedir. Buna göre işletme/kurumlarda genel olarak kadına karşı önyarg1 ve cinsiyet ayrımcılığıyla bağdaşan uygulamaların görüldüğü; bu durumun sonuçları olarak kadın çalışanların mesleki gerginlik, bunalım, fiziksel ve ruhsal çöküş, tükenmişlik, duyarsızlaşma gibi olumsuzluklar yaşadığı anlaşılmaktadır.

Tablo 2: Katılımcıların Denizcilik Sektöründe Kadınların Karşılaştığg Sorunlara Yönelik Algıları

Denizcilik sektöründe kadınların karşılaştığı sorunlarla ilgili aşağıdaki ifadelerden sizin için uygun olanı işaretleyiniz.

\begin{tabular}{|c|c|c|c|c|c|c|c|c|c|c|}
\hline & \multicolumn{2}{|c|}{1} & \multicolumn{2}{|c|}{2} & \multicolumn{2}{|c|}{3} & \multicolumn{2}{|c|}{4} & \multicolumn{2}{|c|}{5} \\
\hline & $\mathrm{n}$ & $\%$ & $\mathrm{n}$ & $\%$ & $\mathrm{n}$ & $\%$ & $\mathrm{n}$ & $\%$ & $\mathrm{n}$ & $\%$ \\
\hline $\begin{array}{l}\text { Denizcilik maskülen (erkeksi) bir meslek } \\
\text { dalı olarak algılanmaktadır. }\end{array}$ & 1 & 1,5 & 12 & 18,1 & 4 & 6,1 & 25 & 37,9 & 24 & 36,4 \\
\hline $\begin{array}{l}\text { Denizcilik sektöründe kadına önyargıyla } \\
\text { bakılmaktadır. }\end{array}$ & 2 & 3,1 & 10 & 15,1 & 5 & 7,5 & 24 & 36,4 & 25 & 37,9 \\
\hline $\begin{array}{l}\text { Denizcilik sektöründe kadınların } \\
\text { çalışmasıyla ilgili kalıplaşmış olumsuz } \\
\text { düşünceler bulunmaktadır. }\end{array}$ & 4 & 6,1 & 8 & 12,1 & 5 & 7,5 & 27 & 40,9 & 22 & 33,4 \\
\hline $\begin{array}{l}\text { Denizcilik sektöründe işe alımda cinsiyet } \\
\text { ayrımcılığ } 1 \text { yapılmaktadır. }\end{array}$ & 6 & 9,1 & 9 & 13,6 & 10 & 15,1 & 21 & 31,8 & 20 & 30,4 \\
\hline
\end{tabular}




\begin{tabular}{|l|l|l|l|l|l|l|l|l|l|l|}
\hline $\begin{array}{l}\text { Denizcilik sektöründe erkekler } \\
\text { kariyerlerinde daha hızlı yükselmektedir. }\end{array}$ & 4 & 6,1 & 10 & 15,1 & 8 & 12,1 & 18 & 27,3 & 26 & 39,4 \\
\hline $\begin{array}{l}\text { Denizcilik sektöründe kadın ve erkek } \\
\text { rollerine göre tanımlar kullanılmaktadır. }\end{array}$ & 1 & 1,5 & 13 & 19,6 & 9 & 13,6 & 19 & 28,8 & 24 & 36,4 \\
\hline $\begin{array}{l}\text { Denizcilik sektöründe erkekler daha fazla } \\
\text { desteklenmektedir. }\end{array}$ & 3 & 4,6 & 11 & 16,6 & 10 & 15,1 & 21 & 31,8 & 21 & 31,8 \\
\hline $\begin{array}{l}\text { Denizcilik sektöründe çalışan kadın ve } \\
\text { erkeklerin sözlerine farklı güven } \\
\text { gösterilmektedir. }\end{array}$ & 6 & 9,1 & 10 & 15,1 & 5 & 7,5 & 19 & 28,8 & 26 & 39,4 \\
\hline $\begin{array}{l}\text { Denizcilik sektöründe kadın ve erkek } \\
\text { çalı̧anlar arasında ücret eşitsizliği } \\
\text { yapılmaktadır }\end{array}$ & 6 & 9,1 & 10 & 15,1 & 13 & 19,6 & 16 & 24,3 & 21 & 31,8 \\
\hline $\begin{array}{l}\text { Denizcilik sektöründe kadın çalışanlara } \\
\text { mobbing uygulanmaktadır. }\end{array}$ & 6 & 9,1 & 8 & 12,1 & 8 & 12,1 & 17 & 25,8 & 27 & 40,9 \\
\hline
\end{tabular}

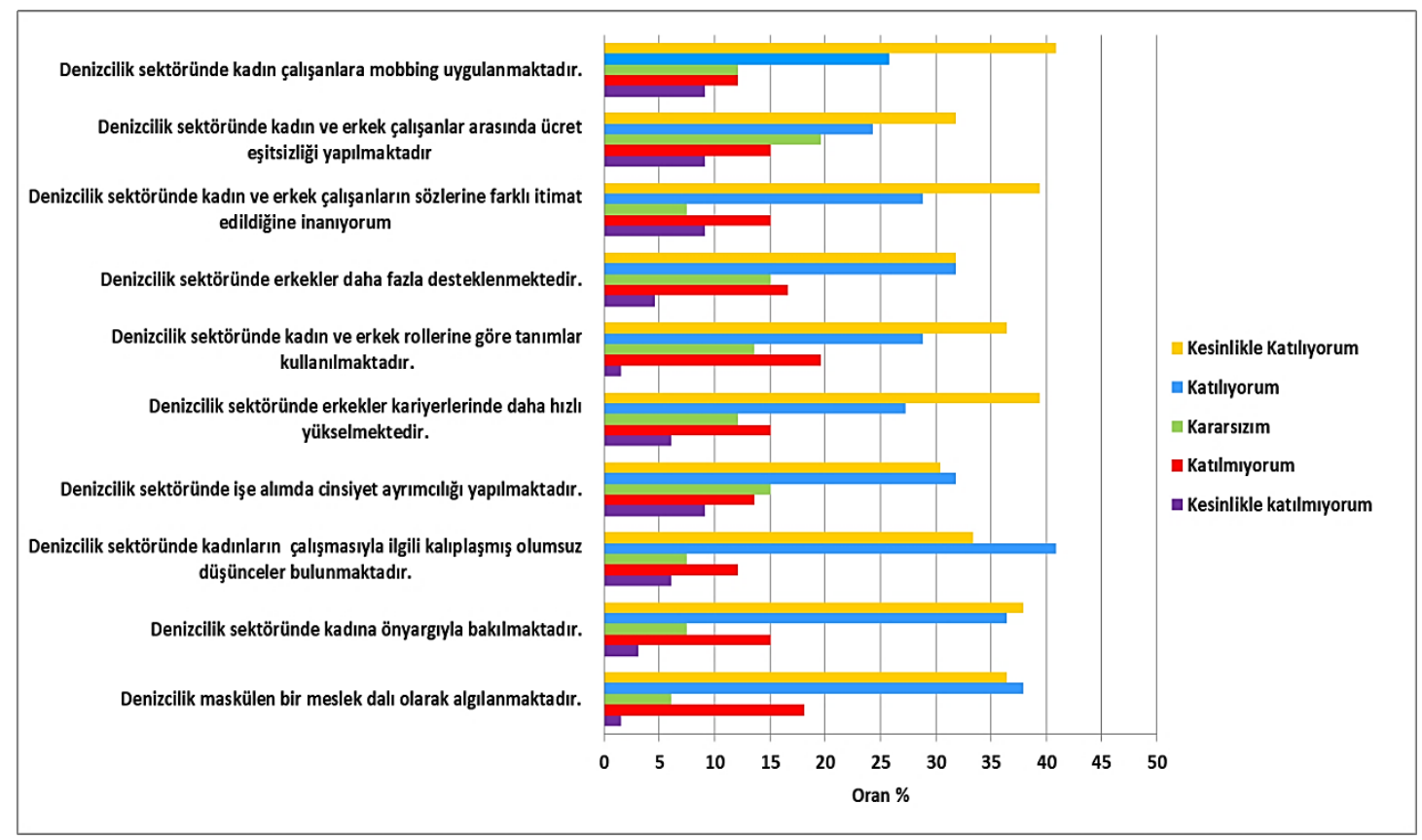

Şekil 1. Katılımcıların Denizcilik Sektöründe Kadınların Karşılaştığı Sorunlara Yönelik Algıları

Katılımcıların denizcilik sektöründe kadınların karşılaştığı sorunlara yönelik algılarını belirleyebilmek üzere oluşturulan sorulara verdiği yanıtlara bakıldığında, "kesinlikle katılmıyorum" yanıtı "Denizcilik maskülen bir meslek dalı olarak algılanmaktadır" ve "Denizcilik sektöründe kadın ve erkek rollerine göre tanımlar kullanılmaktadır" ifadelerine $1(\% 1,5)$ oranlarıyla en düşük katılım sağlanmıştır. Buna göre katılımcılar yüksek oranda denizcilik mesleğini maskülen bir meslek olarak görmekle birlikte, meslekte kadın ve erkek rollerine göre tanımların, işbölümünün ya da çalışma alanlarının bulunduğunu 
düşünmektedirler. En yüksek katılım ise "katılıyorum" yanıtıyla "Denizcilik sektöründe kadınların çalışmasıyla ilgili kalıplaşmış olumsuz düşünceler bulunmaktadır" ve "kesinlikle katılıyorum" yanıtıyla "Denizcilik sektöründe kadın çalışanlara mobbing uygulanmaktadır" ifadelerine 27 (\% 40,9) oranıyla gerçekleşmiştir. Bu durum en düşük ve en yüksek katılım sağlanan ifadelerin birbiriyle ilişkili ve bağlantılı olduğunu göstermekle birlikte, denizcilik sektöründe kadınların cinsiyet ayrımcılı̆ğına dayalı olarak karşılaşı ı̆ı sorunların başında mobbing uygulamaları, kadın ve erkek çalışanların sözlerine farklı güven gösterilmesi, erkek çalışanların kariyerlerinde kadınlara göre daha hızlı yükselmesi ve kadınların sektörde çalışmasıyla ilgili olumsuz düşüncelerin bulunduğunun geldiği görülmektedir.

\section{Sonuç ve Değerlendirmeler}

Kadının iş hayatında yer alması Sanayi Devrimi'yle başlamış, I-II. Dünya Savaşları sonrasında toplam çalışan sayısı içinde yüksek oranlara çıkmıştır. Bu yükselişin nedeni savaşlarla erkek çalışan nüfusunun azalması ve her geçen gün artan sanayi üretiminde emeğe duyulan taleptir. Nitekim iş hayatındaki kadın çalışan sayısının artması, toplumsal bir bakış açısının değişmesinden çok, kadının çalışmasının bir ihtiyaç haline gelmesidir. Bununla birlikte çalıșan kadın sayısının artmasıyla aynı oranda kadının sosyal hakları ve toplumsal statüsü yükselmemiştir. Kadın, kendisi için belirlenen anne ve ev kadınlı̆̆ 1 rolünü görece aşmışsa da, günümüzde dahi kadının toplumsal statüsünün hak ettiği seviyede bulunmadığı da görülmektedir. Kadınların iş hayatındaki yaşadıkları olumsuzluklar da onu sindirmeye ve iş hayatından koparmaya devam etmektedir. 21. yy.'da dahi bir kadının erkeğe göre daha az işlevsel ve kapasitesinin düşük olduğu önyargısı sürmektedir. Bu durum, ataerkil toplumda yaşayan kadının cinsiyet ayrımcılığına maruz kalmaması için verdiği savaşta, üretkenliğinin kısıtlanmasına ve inancının kırılmasına neden olmaktadır. Aynı zamanda iş kadınının bir anne ve eş olarak görevlerini yerine getirmeye çalışması kendisi için büyük bir sorumluluk ve zorluk yaratmaktadır. Kadının bu konularla uğraşırken iş yerinde de psikolojik şiddete maruz kalması (mobbing), kendisini yıldıran ve sömüren bir diğer etkendir. Kişi bu baskılar altında psikolojik sorunlarla karşılaşmakta ve desteğe ihtiyaç duyabilmektedir.

Denizcilik sektörü genel olarak erkek egemen bir mesleki yapıya sahiptir ve kadın çalışanlar için zorlayıcı şartlar içermektedir. Fiziksel şartların olumsuzluğunun yanı sıra sektörde kadına yönelik mevcut olan önyargı ve ayrımcılık kadınların bu sektörden uzak kalmalarına neden olmaktadır. Türkiye'de denizcilik sektöründe kadın çalışanlara yönelik cinsiyetçi önyargıları tanımlamayı ve cinsiyetçi algıları belirlemeyi amaçlayan bu çalışmada elde edilen veriler/sonuçların literatürle benzerlik gösterdiği görülmüsstür. Denizcilik sektöründe kadınlara yönelik cinsiyete dayalı önyargı ve ayrımcılık önemli bir sorun olarak ortaya çıkmaktadır. Araştırma sonucunda çalışanlar tarafindan sektörde yüksek düzeyde kadınlara yönelik cinsiyet önyargıları ve ayrımcılığı algılandığı tespit edilmiștir. Ayrıca literatürde yer alan kadınların erkeklere göre daha fazla mesleki sorunla karşılaștığı gerçeği araştırma sonuçlarıyla da ortaya konmakta ve daha önceki bilgilerle örtüşmektedir. Çalışma hayatlarının ilk yıllarında olumsuzluklarla karşılaşan kadın çalışanlarda çeşitli psikolojik ve ruhsal sorunlar ortaya çıkmakta ve sektöre yönelik ilgi, beklenti ve istekleri göreceli olarak azalmaktadır. $\mathrm{Bu}$ durum genel olarak kadınların sektördeki varlı̆̆ını ve geleceğini etkilemektedir. Bu bağlamda denizcilik sektöründe cinsiyete dayalı sorunların etkilerinin azaltılması ve ortadan kaldırılması için, özellikle genç yaştaki kadın çalışanların desteklenmesi ve mesleki uyumlarının arttırılması önemlidir. Sonuç olarak denizcilik sektörü için cinsiyet eşitliği önemli bir kavram olmakla birlikte, sektörde yer alan tüm işletmelerin, kurum ve kuruluşların, yasa koyucuların, yakın ve uzak çevredeki paydaşların kadın-erkek eşitliği üzerinde önemle durmaları; sorunları çözme ve kadına yönelik cinsiyetçi önyargı ve ayrımcılı̆̆ önleme adına yöntemler geliştirmeleri ve uygulamaları gerekmektedir.

\section{Kaynakça}

Adalar Solmaz, S. (2015). Кamu Sağllk Personelinin Mobbing Karşısındaki Tutumu ve Hukuki Haklarının Bilinirlik Düzeyinin Ölçülmesi, Beykent Üniversitesi Sosyal Bilimler Enstitüsü, Yüksek Lisans Tezi, İstanbul.

Arlı, E. (2013). "Deniz Turizm Sektöründe Algılanan Cinsiyet Ayrımcılı̆̆ı ve Cinsiyet Önyargısı", Çalışma ve Toplum, 3: 283-301.

Aydın, T. (2015). Gemiadamlarının Maslach Tükenmişlik Modeli İle İncelenmesi, Yüksek Lisans Tezi, KTÜ Fen Bilimleri Enstitüsü, Trabzon.

121 | $P$ a g e

www.iiste.org 
Aytaç, S. (1997). Çalışma Hayatında Kariyer Yönetimi Planlaması Geliştirilmesi Sorunları, İstanbul: Epsilon Yayıncilık.

Borovnik, M. (2011). "Occupational Health and Safety of Merchant Seafarers From Kribati and Tuvalu", Asia Pasific Viewpoint, 52 (3): 333-346.

Dardenne, B., Dumont, M., Bollier, T. (2007). "Insidious Dangers of Benevolent Sexism: Consequences for Women's Performance”, Journal of Personality and Social Psychology, 93(5): 764-779.

Davenport, N., Schwartz, R.D., Elliott, G.P. (2003). Mobbing: İşyerinde Duygusal Taciz, (Çev: Osman Cem Önertoy), İstanbul: Sistem Yayıncılık.

Elkins, T.J., Phillips, J.S., Konopaske, R., Townsend, J. (2001). "Evaluating Gender Discrimination Claims: Is There a Gender Similarity Bias?”, Sex Roles, 44(1/2): 1-15.

Foster, M.D. (2000). "Positive and Negative Responses to Personal Discrimination: Does Coping Make a Difference?", Journal of Social Psychology, 140(1): 93-96.

Gemiadamları ve Kılavuz Kaptanlar Yönetmeliği, 10 Şubat 2018 Resmî Gazete Sayı: 30328.

Glick, P., Fiske, S. (1996). "The Ambivalent Sexism Inventory: Differentiating Hostile and Benevolent Sexism", Journal of Personality and Social Psychology, 70(3): 491-512.

IMO, (2019). http://www.imo.org/en/MediaCentre/PressBriefings/Pages/20-World-Maritime-Day2019.aspx. Son Erişim: 02.10.2019

International Labour Organization (ILO) (2016). Women at Work Trends 2016 Executive Summary, Geneva.

Katkat, M. (2000), Kadının Çalışma Hayatındaki Yeri ve Yükselişi, Yüksek Lisans Tezi, Atatürk Üniversitesi, Sosyal Bilimler Enstitüsü, Erzurum.

KSSGM, (1998). 1995 Yılında Pekin'de Gerçekleşen IV. Dünya Kadın Konferansı Sonuçlarının Uygulanması ve İzlenmesine Illişkin Ulusal Eylem Planı, Ankara: KSSGM Yayınları.

Kuleyin B., Köseoğlu B., Töz A.C. (2013). "Liman Çalışanlarının Mesleki Tükenmişlik Seviyelerinin İncelenmesi: Bir Liman Uygulaması", DEÜ Denizcilik Fakültesi Dergisi, 5(2):8396.

Kurt, Ö. (2010). Gemide Çalışma Şartlarının Gemiadamları Üzerindeki Olumsuz Etkileri, Yüksek Lisans Tezi, İTÜ Fen Bilimleri Enstitüsü, İstanbul.

Mahmutoğlu, T. (2017). İş Hayatında Cinsel Ayrımcılık ve Örgütsel Vatandaşlık Davranışı Üzerine Etkileri, Yüksek Lisans Tezi, HÜ Sosyal Bilimler Enstitüsü, Ankara.

Mızrahı, R., Arac1, H. (2010). "Kadın Yöneticiler Ve Cam Tavan Sendromu Üzerine Bir Araştırma”, Organizasyon ve Yönetim Bilimleri Dergisi, 2(1):216-223.

Nemlioğlu Koca, Y. (2015). "Denizcilikte Cinsiyet Ayrımcılığı ve Önyarg1 Algısı: Barbaros Denizcilik Yüksekokulu Öğrencileri Üzerine Bir Araştırma” Çalışma ve Toplum, 44:153-178.

Parrillo,V.N.(2005).Contemporary Social Problems.(6th Edition) U.S.:Pearson Education Inc.

TDK Güncel Türkçe Sözlük. 
Toksöz, G. (2007). "İşgücü Piyasasının Toplumsal Cinsiyet Perspektifinden Analizi ve Bölgeler Arası Dengesizlikler”, Çalışma ve Toplum, 4:57-78.

Yuki, M. (2003). "Intergroup Comparison versus Intragroup Relationships: A Cross-Cultural Examination of Social Identity Theory In North American and East Asian Cultural Contexts", Social Psychology Quarterly, 66:166-183.

Zorba, Y. (2016). "Tükenmişlik Sendromu: Gemi Kaptanları ve Güverte Zabitleri Üzerine Tanımlayıcı Bir Çalışma”, DEÜ Denizcilik Fakültesi Dergisi, 8 (1): 97-127. 